\title{
Reparations in the Caribbean and Diaspora
}

Prilly Bicknell-Hersco

\section{Introduction}

Millions of people have been victim to violent and inhumane social injustices, many of them based on racial and cultural hierarchies. The Nazi Holocaust or the colonization of North America through the genocide of indigenous populations are examples of such instances. When these victims have no direct claim on those who committed the harm, the victims turn to the government for reparations. It can be said that the enslavement of Africans in the Caribbean is another painful and violent injustice, yet few reparations, if any at all, have been paid out to those most affected by the transatlantic slave trade. In 2013, CARICOM released an official request for Reparations for the Native Genocide and Slavery from the United Kingdom and the other European colonies. The discussion of reparations for slavery has ignited debate worldwide.

Transformative justice is a philosophical way of handling conflict and violence. It looks to provide immediate safety, long-term healing, and reparations for victims. Transformative justice attempts to hold those who commit the violence accountable by ending the immediate abuse, committing to avoid abuse in the future, and offering reparations for past abuse. "For reparations to be meaningful, or at least for them to be meaningfully transformative, there needs to be a focus on both the process and outcomes of reparations programs. Moreover, reparations programs need to consider what the intended recipients want and need" (Evans and Wilkes 139). This thought process has led officials to take different approaches to provide reparations, including different policies and procedures beyond exclusively financial payments.

\section{Historical Background}

Perhaps the best-known example of reparations paid to victims of war crimes and injustice came at the end of World War II. In 1952, West Germany signed a Reparations Agreement with Israel to help cover the costs of resettling the Jewish people who were uprooted and to provide compensation to individual Jews for their losses in livelihood and property at the hands of Nazi Germany. This agreement was historical in that both states involved did not entertain a diplomatic relationship, nor did either state wish to establish a relationship moving forward. The negotiations also occurred a mere seven years following the end of the war and made quite an impact because they formally recognized the unspeakable crimes that were committed toward the Jewish people at the hands of the German people. This acknowledgement allowed for the Jewish community and its people to once again be viewed as equals because it placed the blame on those who committed the wrong-doing and not those who fell victim to those acts.

\section{Caribbean Repartition Background}

A 1993 conference in Nigeria called for the Abuja Declaration in which national committees were asked to prepare for a campaign for reparations from all countries that benefitted from slave trade and colonialism. In 2013, CARICOM established the Caricom Reparations Commission (CRC) whose sole purpose was to produce a case for "reparatory justice for the region's indigenous and African descendant communities who are the victims of Crimes against 
Humanity (CAH) in the forms of genocide, slavery, slave trading, and racial apartheid." (CARICOM). In doing so, the CRC was attempting to hold the European government accountable for the hardships endured by the indigenous people of the Caribbean region during the transatlantic slave trade. The CRC contends that the EU is responsible for defining and enforcing African enslavement as well as for refusing to compensate the enslaved once they were freed, even though the government compensated slave owners for the loss of property. It also asserts that there has been no acknowledgment of the crimes committed and, further, that it has imposed racial apartheid among the emancipated.

The justification and political theory addressing reparations for past injustices upon present ancestors of Caribbean slaves have encountered both positive and negative feedback. Codified under international law, reparations have been made to Jewish and Native Americans in terms of free education, health care, and land. However, there have been limited reparations for those of Caribbean ancestry. Reasons for the lack of reparations to those Caribbean communities include a lack of historical data, foreign aid from Britain to the Caribbean region, and the fact that slavery was common practice in the era. There is, however, a quantifiable case for providing such compensation to current Caribbean communities who are descendants of enslaved Africans. Such reasons include a moral obligation and the economic underdevelopment of the region as a direct result of the lack of compensation.

\section{Lack of Historical Data (Ancestry)}

Many who claim reparations are required to provide proof of their ancestry, and the CRC offers case support for these people.

The CRC case for reparations is built upon moral, ethical, and legal arguments, including supporting the idea that contemporary populations still live with and are affected by the legacy of slavery and indigenous genocide. At the foundation of this argument is the belief that those alive today are indeed the descendants of those who were harmed over 150 years ago. Within the Caribbean, this belief is particularly acute, especially with regard to the calls for reparations for indigenous genocide (Torres 2).

While there are significant limitations on historical data, genetic testing can be used as quantifiable proof that contemporary persons of the Caribbean communities are descendants of the indigenous peoples and therefore qualify for reparations.

Genetic testing is quickly becoming a source of evidence with the potential to prove that those currently living in the Caribbean are direct descendants of the indigenous peoples who were harmed by the policies of colonial Britain. Torres states "calculating reparatory measures requires interpretations of the past, an assessment of the present, and an understanding of how both the past and present are related. In order to strengthen this legal case, a crucial aspect of CARICOM's argument would be to establish that contemporary populations have indeed been impacted by the legacy of Britain's colonial policies" (3). Genetic data can provide a missing piece of evidence necessary to reconcile the history of unaddressed abuse and exploitation of Black and Indigenous people. 


\section{Past and Current Reparation of Others}

Another argument as to why the Caribbean region has yet to receive reparations from Europe is the amount of foreign aid that is currently being received. In America, the Native American population has received reparations in the form of federal aid through Congressional legislation for more than a century (Danielson and Pimentel 90). CARICOM states already receive over $\$ 450$ million per year in foreign aid from Europe, and a large amount of that comes from the three nations being targeted for reparations: Great Britain, France, and the Netherlands. Based on this information, it is suggested that if CARICOM were to be awarded reparations, this monetary amount would come from the budget that is already intended for foreign aid.

The financial reparations that are requested from the European Union are not necessarily in the form of individual payments to the descendants of the indigenous people, but more focused on providing infrastructure to the region. "It is a renewed call for development cooperation between Britain and the Caribbean. It is about Britain making a long-overdue contribution to the economic development of the Caribbean through investments in areas such as education, health care, agriculture reform, technology, and science to transfer through the universities and colleges"(Erskine 2). According to the Lisbon Treaty of 2009, a vital objective of the "EU's policy on foreign aid is the reduction and eventual elimination of poverty," including but not limited to helping to restore social infrastructures such as education and healthcare (Papademetriou 6).

It is also assumed that Europe and the United States would cut down on the otherwise regular donations for regional development. "A reparation settlement would be another blow to a European economy struggling to recover. Further, since the EU is the second-largest trading partner with CARICOM, anything that negatively impacts the EU economy will most assuredly harm Caribbean economies" (Edghill 2).

\section{Precedence}

In order to receive reparations under International Law, CARICOM must be able to prove that their colonial oppressors acted illegally at the time they carried out their injustices (Schwartz). While slavery is, without a doubt, an inhumane injustice, at one point in time, it was legal. Slavery was once thought to be more of a business than an injustice. This does not excuse the individuals who participated in the slave trade from their complicity, but it is important to understand the bigger issue of colonial powers creating structures and policies that even allowed slavery to be legal.

In 1996, a motion for reparations was denied by the House of Lords based on the fact that those unjust acts occurred in the distant past, and there were no living persons to act as a plaintiff in the case (Schwartz). Accountability and compensation for slavery are often refused simply because those injustices were restricted to the period in which it happened. Those in favour of reparations argue that the responsibility of the wrongdoing cannot be transferred from one point in history to the current time. Those beliefs persist today. In 2018, Secretary-General António Guterres had this to say about the transatlantic slave trade: "It was inhuman. It was shameful. 
However, it was legally sanctioned - conducted and condoned by leaders and countries in Europe, the Americas, and elsewhere." To provide reparations in the Caribbean would set a precedent for all descendants of slaves to receive reparations. The call for reparations from CARICOM has already been linked to the Black Lives Matter movement, which has led to a reopening of the reparation discussion for African Americans in the United States (and across the wider diaspora)(CARICOM).

In 2007, Anthony Gifford wrote, "If the transatlantic slave trade was a crime against humanity, it was a crime in international law and a suitable case for reparations" (93). The strong impact that Britain had on the transatlantic slave trade should result in a moral obligation to make amends for their part. This is exemplified in the lasting effects that many black people throughout the world still encounter today. In 2018, Mone Dixon submitted a thesis to the City University of New York that examined the link between slavery and the mistreatment of African Americans today. Dixon stated,

the mentality that established and supported the system of slavery, which promoted the dehumanization of Black bodies, remains a reality today and keeps African Americans more susceptible to state violence. The ongoing volatile acts committed by police officials onto Black bodies, as well as the nation's blatant disregard of racism, have caused an uproar within the Black community. Hence, the rise of the Black Lives Matter movement (33).

Dixon was not the first, and will not be the last, to make this connection between the exploitation of black people and the continuous economic disadvantages as social stratification.

Britain, along with other countries, enjoyed significant economic benefits from slavery. Most continue to do so. There is a moral obligation to provide support to their former colonies for long-term development that is sustainable, especially considering the physical state of the lands after colonial powers extracted all of their natural resources. The substantial role that Britain played in the transatlantic slave trade should be acknowledged. Recognizing their role in the slave trade is one small step in the direction of reparations. Just as West Germany apologized for the actions of the Nazis, similarly, Britain has an obligation to apologize for the exploitation and violence inflicted upon Black bodies, regardless of how much time has passed.

Compensation given to British, Spanish and Portuguese slave owners after the abolition of slavery played a large part in the industrial development of those countries. "In 1833, Britain used $£ 20$ million, $40 \%$ of its national budget, to buy freedom for all slaves in the Empire. The amount of money borrowed for the Slavery Abolition Act was so large that it wasn't paid off until 2015." (HM Treasury). If taxpayers today are still making up for the debt incurred centuries ago from "compensated emancipation," today's descendants of those enslaved should have the same right to be compensated, regardless of time restraints. Nothing was paid to those who suffered from being enslaved, and no land was given. This impeded the growth of "industrialization and caused chronic poverty." Manjapra also notes that the Caribbean has become one of the largest centers of predatory lending at the hands of the IMF and World Bank, as well as European and American banks, as a direct result of their "historical enforced dependence on foreign finance" (125). 
It has been argued that there is a real and present need for an acknowledgment of the significance of the legacy that transatlantic slave trade left behind. Not only did the Caribbean lose labor forces to the slave trade, but the profits made from slavery and sugar were distributed to European nations. The economic effects of those relationships built globally during the colonial period are still evident today and continue to hinder the economic growth of the Caribbean region (Evans and Wilkins 145). The financial burden that continues to affect the region negatively stems from the economic history that was established during the transatlantic slave trade.

\section{Economic Inequalities}

The economic inequalities resulting from the transatlantic slave trade also spread throughout the Caribbean region, including the underdevelopment that exists within localized populations tying into historical practices. Emancipated slaves were alienated and received no land, putting productive resources out of their reach. Even the descendants of the once enslaved were refused inheritance because their ancestors had not received payment for their work.

At the time slavery was abolished, little was paid to the Caribbean region for education. The impact of well-educated individuals that flee the Caribbean due to the slow rate of economic growth within the region was examined by Mandle in 2011. While federation is considered a "cornerstone of burgeoning West Indian nationalist movements" (Duke), becoming a nation has not been a high priority for those living in the Caribbean. The lack of progress of integration has negatively impacted the economic growth of the region. In order to successfully build a nation, the new Caribbean must be strong enough to overcome the former Caribbean. Until then, the people in the Caribbean continue to look to migration as a means to achieve better economic security. This then perpetuates the idea that the only way to attain success is to be found outside of the Caribbean borders.

Mandle concluded that, while continuing education elsewhere is not inherently harmful, the focus must be for those to return once the training or education is completed. "What is fundamental to modern growth is the competence of a population to work in a complementary relationship with modern technology". Reparations could potentially lead to a federation of Caribbean states and raise the overall economic status, which would, in turn, encourage development. The development could, in turn, reduce the rate of those well-educated persons who leave the Caribbean for more developed countries. The University of the West Indies has the capacity to become a "hub of technologically sophisticated research and development" (Mandle), which could contribute to the return of the Caribbean people. However, funds are needed to see this project to fruition. The reparations that CARICOM is seeking could have a significant impact on the development of this university.

\section{Transatlantic Slavery, Present-Day Benefits, And Harms}

The influence that integration resulting from slavery has had on the identity of the Caribbean region remains. "In this region, indigenous populations, the African Diaspora created by slavery, and European settlers provided the human basis upon which plantation economies built unique 
but analogous social, political and economic institutions and cultures" (Garcia). Garcia explained how nearly all aspects of Caribbean culture are more or less extensions of other parts of the world, from the music of Afro Antillean drums to food with Puerto Rican roots.

The roots of the indigenous people continue to play a significant role in today's culture of the Caribbean region. In historical and cultural terms, a Caribbean identity can be conceived as a set of overlapping circles. The segment of the surface of each circle that overlaps (music, cuisine, religious beliefs, etc.) constitutes the building block of a Caribbean identity. It is further argued that this "cultural core" is provided by the Afro-Antillean Diaspora traditions. The shared yet diverse experience(s) of slavery and plantation are the basis of the cultural bond captured in Walcott's affirmation, the driving force behind the "emotional federation."

It is also imperative to note that, just as integration has impacted the culture of the Caribbean region, the ideas central to the function of slavery continues to permeate Caribbean society today. "It appears that the racial hierarchies of chattel slavery still influence socioeconomic realities both within and between nations that were historically engaged in the transatlantic slave trade" (Evans and Wilkins). Much evidence still exists for the connections between transatlantic slavery and present-day benefits and harms. When looking at the heart of the structure of inequalities, slavery is found and persists today throughout the world.

A press release from the United Nations in 2018 quoted Martha Ama Akyaa Pobee of Ghana, who aregued that the remnants of the slave trade in her country were visible today. She pointed out that more than 40 million people worldwide were trapped in modern-day slavery in the form of forced labor, forced prostitution, human trafficking, child labor, and forced marriage. Yet, while the Transatlantic slave trade had devastating consequences in Africa, the resilience and survival of its victims had inspired change, especially for Africa's decolonization and the Pan-Africanist movement.

The racial hierarchies that were established to justify the transatlantic slave trade persists today in the Caribbean. Those of white or light skin are still typically considered to be among the elite or upper-class. It is possible that the result of the formal apology and admittance that comes with the 10-Point Plan for reparations laid out by the CRC could be as beneficial to black people in the region as reparations were for the Jewish after the agreement with West Germany in 1952. Gifford states, "every act of discrimination, every racial attack, every vote for a neo-Fascist party, is a reminder that the doctrine of white superiority, which was used to justify the traffic in Black humans, still has potency."

The relationship between present racial inequalities and slavery practices have been studied and examined by a vast number of scholars. The results of these studies directly "point to the widespread destruction of languages and culture that went hand in hand with the mass enslavement of Black populations and the classification of such as less than human beings, the denial of a cultural voice and ability to practice traditions and the stunting of the development of educational systems and cultural institutions which were not developed within the Caribbean region because of the structure of slave societies" (Schwartz). 


\section{Conclusion}

There is a case for reparations to be paid out because of the enslavement of black people and the colonization of indigenous land. Though there is a more significant gap in time from when the injustices occurred and when reparations were given, Jewish communities and indigenous (Native American) communities received reparations for similar circumstances. While time has passed, this does not erase the devastating legacies of slavery. Countries that participated in the slave trade, who bought, sold and enslaved Africans in the Caribbean, benefited financially from the slave trade and were able to maintain their wealth and power, and build generational wealth from the blood of enslaved Black people during transatlantic slave trade. Likewise, many Black people across many continents have not been able to economically recover and thus have been in a state of financial dependency, making it difficult to build generational wealth. In essence, the Caribbean is comprised of third world countries as a direct result of being enslaved and colonized, thus, reparations must be considered in some capacity in order to achieve and maintain economic stability and independence across the region. 


\section{Works Cited}

CARICOM. (2019). 10-point reparation plan. CARICOM. Retrieved from http://caricomreparations.org/caricom/caricoms-10-point-reparation-plan/

Danielson, M., \& Pimentel, A. (2004). Give them their due: An African-American reparations program based on the Native American federal aid model, Washington and Lee Journal of Civil Rights and Social Justice 10(1), 89-114.

Dixon, M. (2018). The influence of slavery on the black body: Black lives matter's intersectional methodology and new advancements (Unpublished doctoral dissertation). New York, NY, CUNY.

Edghill, M. (2013). CARICOM and reparations. Americas Quarterly. Retrieved from https://www.americasquarterly.org/content/caricom-and-reparations

Erskine, M. (2016). Sir Hilary presents model for reparations at Oxford University. UWI St. Augustine. Retrieved from http://sta.uwi.edu/news/releases/release.asp?id=1519

Evans, M. and Wilkins, D. (2019). Transformative justice, reparations, and transatlantic slavery, Social and Legal Studies, 28(2), 137-157.

Gifford, A. (2007). Pipe dream or necessary atonement? Index on Censorship, 36(1), 8996. doi:10.1080/03064220701224439

Papademetriou, T. (2011). European union: Regulation of foreign aid - September 2011, The Law Library of Congress. 19-44.

Schwartz, K. (2014). Bars to recovery: The Caribbean claims to reparations to slavery in international law (Unpublished doctoral dissertation). New Zealand: University of Otago.

Torres, J. (2018). 'Reparational' genetics: Genomic data and the case for reparations in the Caribbean. Genealogy, 2(1), 7-21. doi:10.3390/genealogy201007 
United Nations Press Release. (March 26, 2018). Nefarious impacts of slavery, transatlantic slave trade persist today, speakers stress as general assembly observes international day amid calls to end racism. United Nations Retrieved from https://www.un.org/press/en/2018/ga12005.doc.htm 